Rev. Inst. Med. trop. S. Paulo

39 (3): 177-179, maio/junho, 1997

\title{
BRIEF COMMUNICATION THE FIRST TWO CASES OF Cyclospora IN DOGS, SÃO PAULO, BRAZIL
}

Lúcia Eiko Oishi YAI (1), Antonieta Rosa BAUAB (1), Marisa Porta Miche HIRSCHFELD (2), Maria Lúcia de OLIVEIRA (1) \& José Theodoro DAMACENO (1).

\begin{abstract}
SUMMARY
Cyclospora cayetanensis is a coccidium which has been identified in diarrheal feces or immunocompetent individuals or in AIDS patients. The main aspects related to its epidemiology and pathogeny have not been solved so far, as well as the possibility of human infection by this protozoan being a zoonosis. We describe in this work the first case identifying the Cyclospora in dogs. Our findings, notwithstanding their preliminary characteristics, could suggest that besides untreated water, other transmission means, along with contact with dogs, there could be important factors in the human diarrhea associated with Cyclospora.
\end{abstract}

KEYWORDS: Coccidia; Cyclospora; Dog; Zoonosis.

Several international early reports have described the detection of spherical organisms $(8-10 \mu \mathrm{m}$ in diameter) in the stool of persons with watery diarrhea '. These large organisms, often called blue-green algae (Cyanobacterium-like body) or coccidian-like bodies have been associated mainly with infection in immunocompetent travelers ${ }^{6}$ and in patients with AIDS ${ }^{9}$. In addition, recent reports have described outbreaks of diarrhea associated with Cyclospora in the United States ${ }^{3}$. The illness was characterized by watery diarrhea, abdominal cramping, anorexia and low-temperature fever ${ }^{10}$.

Recently, ORTEGA et al. have recognized the organism as members of the genus Cyclospora on the basis of its sporulation and excystation characteristics (during sporulation, the oocyst produces two sporocysts, each containing two sporozoites) and have proposed the name Cyclospora cayetanensis to this new species ${ }^{7,8}$.

Many questions still have to be answered about epidemiological characteristics of human Cyclospora. As Cyclospora parasites are released into the environment via stool, human beings and animals infected with Cyclospora could become sources of infection.

At the present time, however, the detection of Cyclospora in the stool of dogs has not been demonstrated. GARCÍALOPES et al. in 1996, found C. cayetanensis in the pouled feces from approximately 600 chickens from a poultry farm near Monterrey. Whether human Cyclospora infection may be a zoonosis is still unknown.

We describe in this report the first two Cyclospora cases identified in dogs in the world.

\section{CASE 1}

In December 1995, spherical cyst-like organisms, resembling large Cryptosporidium $s p$, were observed in the feces of a dog (Siberian Husky): male, 4-months-old, with a 20day history of watery diarrhea. The dog experienced vomiting, weight loss and lethargy. Routine parasitological exams were negative for known ova and other parasites. The organism observed on direct examination and after concentration in formaldehyde-ether were nonrefractile spherical bodies of 8 to $10 \mu \mathrm{m}$ in diameter, containing a cluster of refractile globules, enclosed within a membrane. With the Ziehl-Neelsen method, the organisms were variable acid-fast, staining deep red or pink or not staining at all appearing as "ghosts" (Fig. 1). Also, the sediment was examined by epifluorescence with use of a ultraviolet filter and the oocysts appeared autofluorescent.

Feces were preserved in 2.5 percent potassium bichromate at room temperature to study sporulation. After one week, some organisms appeared with two sporocysts (Fig. 2). Based

(1) CENTRO DE CONTROLE DE ZOONOSES, Prefeitura Municipal de São Paulo, SP, Brasil.

(2) Faculdade de Ciências Farmacêuticas da Universidade de São Paulo, SP, Brasil.

Correspondence to: Lúcia Eiko Oishi Yai, Centro de Controle de Zoonoses da Prefeitura Municipal de São Paulo, Rua Santa Eulália 86, 02031-020 São Paulo, SP, Brasil. Telefone: (55-11) 290-9755, ramal 246. FAX: (55-11) 299-9823. 

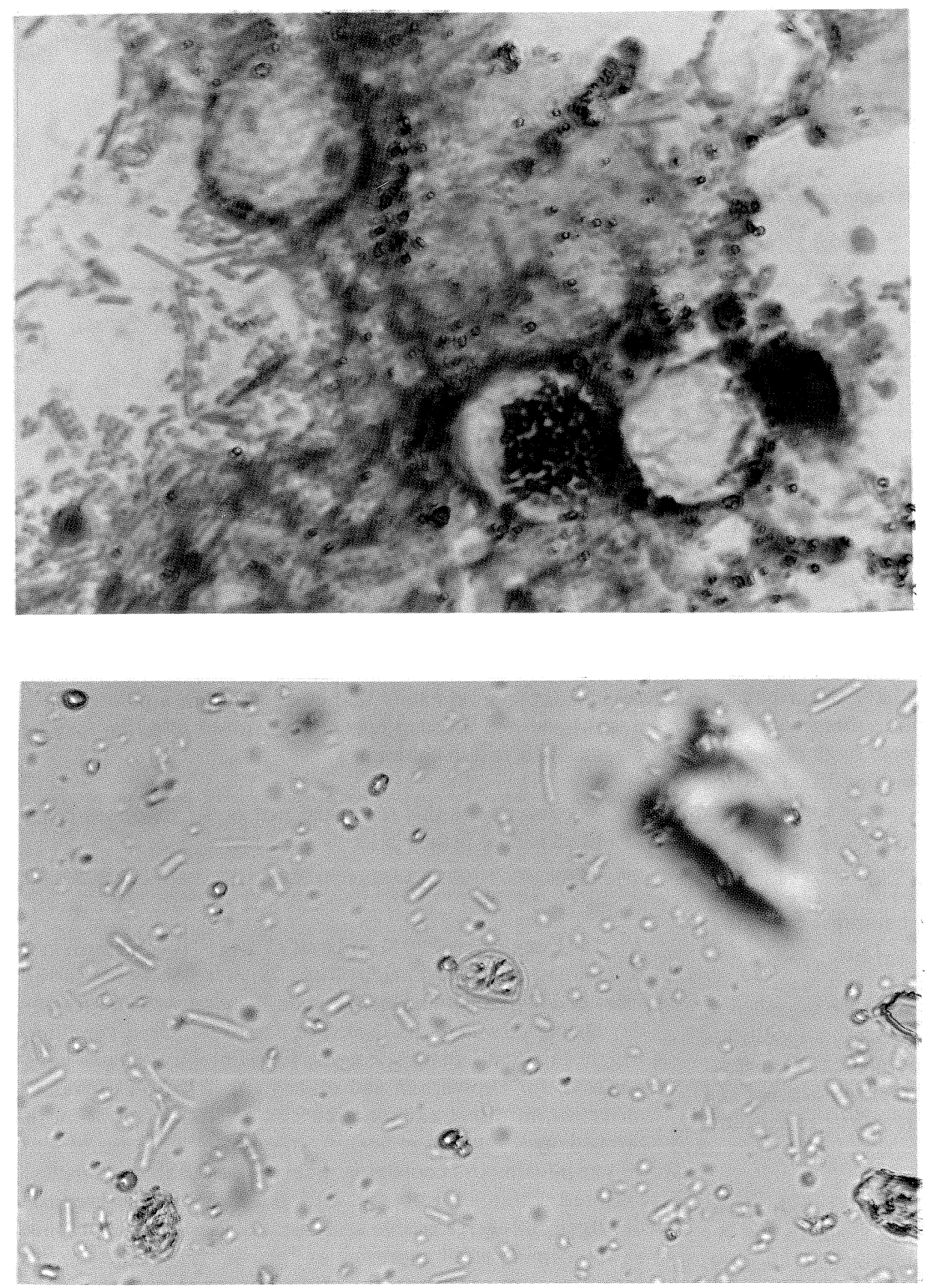

Fig 1 - Morphologic and staining characteristics of Cyclospora. Oocyst stained purple to red with Ziehl-Neelsen modified stain (x 1000)
Fig 2 - Sporulated oocyst of Cyclospora with two sporocysts seen in direct wet mount. (x 400) on these characteristics the oocysts were identified as Cyclospora ${ }^{4,8}$.

The dog was treated with a daily dosage of $500 \mathrm{mg}$ of Tinidazole for 3 days, but the diarrhea did not cease. Another treatment with $400 \mathrm{mg}$ of Chloramphenicol twice daily for 7 days was attempted and complete resolution of symptoms was noted. After 10 days, a new examination of stool was performed and the result was negative to Cyclospora.

\section{CASE 2}

In June 1996, we identified the same oocyst seen in the first case in the feces of a dog (Rottweiler): male, 1-year-old, with a 5-day history of watery diarrhea, dehydration, anorexia and diffuse abdominal sensibility. The dog was treated with $80 \mathrm{mg}$ of trimethoprim and $400 \mathrm{mg}$ of sulphamethoxazole twice daily for 7 days and complete resolution of symptoms was noted. After 10 days, a new examination of stool was performed and the result was negative to Cyclospora. 
YAI, L.E.O.; BAUAB, A.R.; HIRSCHFELD, M.P.M.; OLIVEIRA, M.L. de \& DAMACENO, J.T. - The first two cases of Cyclospora in dogs, São Paulo, Brazil. Rev. Inst. Med. trop. S. Paulo, 39 (3): 177-179, 1997.

We reviewed all pertinent literature regarding infection with Cyclospora species, but the zoonotic potential for animals to serve as reservoirs for the transmission of Cyclospora to other animals, including man, has not been evaluated.

Organisms of the genus Cyclospora have been previously found in rodents ${ }^{2}$, reptiles, myriapods ${ }^{10}$, and insectivores ${ }^{5}$. The Cyclospora species reported in those animals, however, are sufficiently different from those identified in this present study.

The Cyclospora that we identified in the dogs, seems to be the same species found in humans (Cyclospora cayetanensis). These findings although preliminary, may be suggesting that besides consumption of untreated water, additional modes of transmission such as contact with dogs may be important in human diarrhea illnesses associated with Cyclospora.

In addition, probably Cyclospora may be a dog enteric pathogen able to produce diarrhea, and it should be considered in assessments of dogs with unexplained diarrhea illness.

\section{ACKNOWLEDGEMENTS}

The authors would like to thank Govinda Vivesvara from Centers for Disease Control and Prevention, Atlanta, USA and Hercules Moura from Universidade Estadual do Rio de Janeiro for their assistance in confirming the diagnosis.

\section{RESUMO}

\section{Primeiros dois casos de Cyclospora em cães, São Paulo, Brasil}

Cyclospora cayetanensis é um coccídeo que tem sido identificado em fezes diarréicas de indivíduos imunocompetentes e em pacientes com Aids. Os principais aspectos relacionados à sua epidemiologia e patogenia ainda não estão bem elucidados, bem como a possibilidade da infecção humana por este protozoário ser uma zoonose. Neste trabalho, descrevemos os primeiros casos de identificação de Cyclospora em cães. Nossos achados, embora preliminares, podem sugerir que além de água não tratada, outras formas de transmissão, assim como contato com cães, possam ser importantes na doença diarréica humana associada com Cyclospora.

\section{REFERENCES}

1. BERLIN, O.G.W.; NOVAK, S.M.; PORSCHEN, R.K. et al. - Recovery of Cyclospora organisms from patients with prolonged diarrhea. Clin. infect. Dis., 18: 606-609, 1994.

2. FORD, P.L.; DUZINSKI, D.N. \& Mc ALLISTER, C.T. - Coccidia (Apicomplexa) from heteromyd rodents in the south western United States, Baja California and northern Mexico with three new species from Chaetodipus hispidus. J. Parasit., 76: $325-331,1990$

3. HUANG, P.; WEBER, J.T.; SOSIN, D.M. et al. - The first reported outbreak of diarrheal illness associated with Cyclospora in the United States. Ann. intern. Med., 123: 409-414, 1995.

4. LONG, E.G.; WHITE, E.H.; CARMICHAEL, W.W. et al. - Morphologic and staining characteristics of a Cyanobacterium - like organism associated with diarrhea. J. infect. Dis., 164: 199-202, 1991.

5. MOHAMED, H.A. \& MOLYNEUX, D.H. - Developmental stages of Cyclospora talpae in the liver and bile duct of the mole (Talpa europaea). Parasitology, 101: 345-350, 1990.

6. OOI, W.W.; ZIMMERMAN, S.K. \& NEEDHAM, C.A. - Cyclospora species as a gastrointestinal pathogen in immunocompetent hosts. J. clin. Microbiol., 33: 1267-1269, 1995.

7. ORTEGA, Y.R.; STERLING, C.R.; GILMAN, R.H.; CAM, V.A. \& DIAZ, F. Cyclospora cayetanensis a new protozoan pathogen of humans. Amer. J. trop. Med. Hyg., 47: 210, 1992.

8. ORTEGA, Y.R.; STERLING, C.R.; GILMAN, R.H.; CAM, V.A. \& DIAZ, F. Cyclospora species - a new protozoan pathogen of humans. New Engl. J. Med., 328: $1308-1312,1993$.

9. PAPE, J.W.; VERDIER, R.I.; BONCY, M.; BONCY, J. \& JOHNSON, W.D. Cyclospora infection in adults infected with HIV. Clinical manifestations, treatment and prophylaxis. Ann. intern. Med., 121: 654-657, 1994.

10. WURTZ, R. - Cyclospora: a newly identified intestinal pathogen of humans. Clin. infect. Dis. 18: 620-623, 1994.

Recebido para publicação em 25/02/1997

Aceito para publicação em 24/06/1997 
